\title{
Fusobacterium alocis sp. nov. and Fusobacterium sulci sp. nov. from the Human Gingival Sulcus
}

\author{
ELIZABETH P. CATO, ${ }^{*}$ LILliAN V. H. MOORE, AND W. E. C. MOORE \\ Department of Anaerobic Microbiology, Virginia Polytechnic Institute and State University, Blacksburg, Virginia 24061
}

\begin{abstract}
Two new species, Fusobacterium alocis and Fusobacterium sulci, are described. They were isolated principally from subgingival areas associated with gingivitis or periodontitis. Strains of these species were nonreactive in the biochemical tests usually used and were differentiated most readily from each other and from other Fusobacterium species by patterns of soluble cellular proteins determined by polyacrylamide gel electrophoresis. The type strains of the species are F. alocis ATCC 35896 and F. sulci ATCC 35585.
\end{abstract}

During studies of the bacterial flora of gingival sulci of humans with gingivitis or periodontitis, we found that 170 isolates from 77 samples from 44 different persons had characteristics distinct from those of any species previously described. Cells of these isolates were nonsporeforming, gram-negative, obligately anaerobic rods that produced butyrate but not isobutyrate or isovalerate from peptone. They were, therefore, members of the genus Fusobacterium (7). By differential criteria presently accepted $(1,7)$, the isolates phenotypically resembled $F$ usobacterium russii: neither carbohydrates nor proteins were attacked, esculin was not hydrolyzed, propionate was not formed from threonine, and indole was not produced. However, electrophoretic patterns of soluble cellular proteins were quite distinct from those of not only $F$. russii strains but also all the described Fusobacterium species.

In previous papers $(5,6,8-11)$, we had separated these strains into three species, $F$. russii D (dental $F$. russii), Fusobacterium D2, and Fusobacterium D9, on the basis of differences in growth characteristics (Fusobacterium D2 and D9 grew more slowly and more poorly than did $F$. russii D), motility (Fusobacterium strain D9 often showed a twitching or end-over-end type of motility), and hydrogen production $(F$. russii $\mathrm{D}$ usually produced abundant hydrogen, and the others produced little or none). However, since these strains grew poorly, identification by these criteria could not be made with confidence. When strains of the three groups were subjected to polyacrylamide gel electrophoresis, two distinct patterns of soluble cellular proteins emerged.

Because only 3 of the 170 isolates were from healthy gingival crevices and because the isolates were found in more subgingival than supragingival samples (67 subgingival of 77 total positive samples), these strains may be significant in the development of human periodontitis. For these strains we propose the following new species and type strains: Fusobacterium alocis VPI D40B-5 (=ATCC 35896) and Fusobacterium sulci VPI D45A-29A (=ATCC 35585).

\section{MATERIALS AND METHODS}

All isolates were from supragingival or subgingival samples taken as described previously $(9,10)$.

Reactions were determined in prereduced, anaerobically sterilized media by anaerobic methods described in the Anaerobe Laboratory Manual (1). Patterns of soluble cellular proteins were determined by polyacrylamide gel electrophoresis without sodium dodecyl sulfate (4).

\footnotetext{
* Corresponding author.
}

John L. Johnson determined the guanine-plus-cytosine content of DNA from each type strain by the thermal melting point method $(2,3)$.

Antibiotic susceptibilities were tested by the broth-disk method of Wilkins and Thiel (12).

\section{RESULTS AND DISCUSSION}

Fusobacterium alocis sp. nov. (a'lo.kis. Gr. n. alox a furrow; N.L. gen. n. alocis of a furrow, referring to its isolation from a crevice of the gums). Cells are gramnegative, nonsporeforming, obligately anaerobic rods, 0.4 to 0.7 by 1.5 to $7.0 \mu \mathrm{m}$, with rounded to tapered ends. They occur singly, in pairs, or occasionally in short chains. Of 117 strains, 6 have slow twitching or end-over-end type of motility, but flagella are not detected.

Surface colonies on anaerobic blood agar plates are pinpoint to $1.0 \mathrm{~mm}$, circular, entire, flat to low convex, translucent to transparent, shiny, smooth, and nonhemolytic. No internal colony structure is visible.

The optimum temperature for growth is $37^{\circ} \mathrm{C}$, at which growth is only moderate at best. Slight growth occurs at 30 and $45^{\circ} \mathrm{C}$; there is little or no growth at $25^{\circ} \mathrm{C}$. Growth can be stimulated by the addition of rabbit serum (final concentration, 10 to $15 \%$ [vol/vol]) and cocarboxylase (final concentration, $5 \mu \mathrm{g} / \mathrm{ml}$ ). Most strains grow better in an atmosphere of $10 \% \mathrm{CO}_{2}-90 \% \mathrm{~N}_{2}$ than of $100 \% \mathrm{CO}_{2}$.

Cultures in peptone-yeast extract-glucose (PYG) broth have a fine granular sediment and no turbidity after incubation for 5 to 7 days. The final pH of cultures in PYG broth and in basal medium incubated in a $\mathrm{CO}_{2}-\mathrm{N}_{2}$ atmosphere is 6.8 to 7.1 ; under $100 \% \mathrm{CO}_{2}$, the final $\mathrm{pH}$ of each is 5.9 to 6.1 .

Although little or no gas is formed in PYG deep agar cultures, abundant $\mathrm{H}_{2}$ is detected in the headspaces of broth cultures when there is sufficient growth. No $\mathrm{H}_{2} \mathrm{~S}$ is detected in sulfide-indole-motility medium (BBL Microbiology Systems). No acid is produced from adonitol, amygdalin, Larabinose, cellobiose, dextrin, dulcitol, meso-erythritol, esculin, D-fructose, D-galactose, D-glucose, glycerol, glycogen, inositol, inulin, lactose, maltose, D-mannitol, D-mannose, melezitose, melibiose, pectin, raffinose, rhamnose, D-(-)ribose, salicin, D-sorbitol, L-sorbose, starch, sucrose, trehalose, or D-xylose. Indole, acetylmethylcarbinol, catalase, lecithinase, lipase, urease, oxidase, and deoxyribonuclease are not produced. Esculin, starch, and hippurate are not hydrolyzed. Nitrate is not reduced; neither resazurin nor neutral red is reduced. There is no reaction in milk and no digestion of gelatin or chopped meat. 


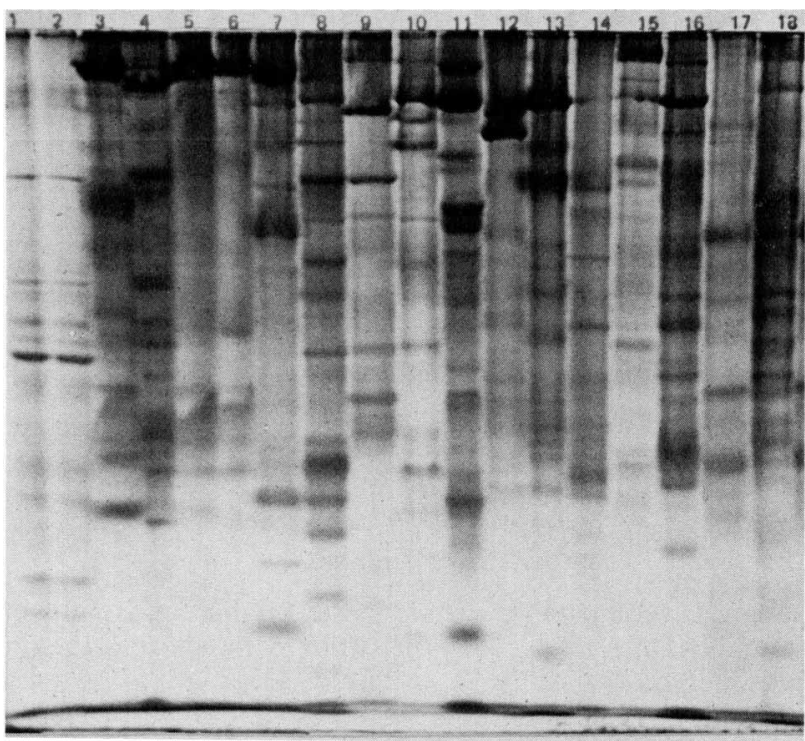

FIG. 1. Polyacrylamide gel electrophoresis protein patterns of the type strains of species in the genus Fusobacterium. Lanes 1 and 2, Streptococcus faecalis U4-20, a reference strain; lanes 3 through $6, F$. nucleatum ATCC $25586^{\mathrm{T}}$ (lane 3), VPI 4355 (lane 4), VPI 14D4 (lane 5), and VPI E1D1 (lane 6) (these strains have the phenotypic characteristics of $F$. nucleatum but are distinct genetic subgroups [Y. Selin and J. L. Johnson, J. Dent. Res. \{Special Issue A\} 60:415, abstr. no. 420,1981$]$ ); lane $7, F$. gonidiaformans ATCC $25563^{\mathrm{T}}$; lane $8, F$. mortiferum ATCC $25557^{\mathrm{T}}$; lane $9, F$. naviforme ATCC $25832^{\mathrm{T}}$; lane $10, F$. necrogenes ATCC $25556^{\mathrm{T}}$; lane $11, F$. necrophorum ATCC $25286^{\mathrm{T}}$; lane $12, F$. perfoetens ATCC $29250^{\mathrm{T}}$; lane $13, F$. periodonticum ATCC $33693^{\mathrm{T}}$; lane $14, F$. prausnitzii ATCC $27768^{\mathrm{T}}$; lane $15, F$. russii ATCC $25533^{\mathrm{T}}$; lane $16, F$. simiae ATCC $33568^{\mathrm{T}}$; lane $17, F$. sulci ATCC $35588^{\mathrm{T}}$; lane $18, F$. varium ATCC $8501^{\mathrm{T}}$.

The products of fermentation in PYG broth are small to moderate amounts of butyrate and acetate. Pyruvate, DLlactate, D-gluconate, and DL-threonine are not utilized.

All tested strains are susceptible to chloramphenicol (12 $\mu \mathrm{g} / \mathrm{ml})$, clindamycin $(1.6 \mu \mathrm{g} / \mathrm{ml})$, erythromycin $(3 \mu \mathrm{g} / \mathrm{ml})$, and tetracycline $(6 \mu \mathrm{g} / \mathrm{ml}) ; 1$ of 20 strains tested is resistant to penicillin $(2 \mathrm{U} / \mathrm{ml})$.

The principal habitat of $F$. alocis is the human gingival sulcus. It has been isolated from a submandibular abscess and from a mouth ulcer.

The type strain of $F$. alocis is VPI D40B-5 (=ATCC 35896). The guanine-plus-cytosine content of the DNA of this strain is $34 \mathrm{~mol} \%$.

Fusobacterium sulci sp. nov. (sul'ki. L. gen. n. sulci of a furrow, referring to its habitat, the human gingival sulcus.

Cells are gram-negative, nonmotile, nonsporeforming, obligately anaerobic, straight rods, 0.4 to 0.7 by 1.0 to 7.0 $\mu \mathrm{m}$, with rounded ends. They occur singly, in pairs, or in short chains, often with cells of different sizes in the same chain.

Surface colonies on blood agar plates are pinpoint to 1.0 $\mathrm{mm}$, circular, entire, flat to low convex, translucent, colorless, shiny, smooth, and nonhemolytic. No internal colony structure is visible.

The optimum temperature for growth is $37^{\circ} \mathrm{C}$, at which growth is only moderate at best. No growth occur at 25 or $45^{\circ} \mathrm{C}$. Growth can be stimulated by the addition of rabbit serum (10 to $15 \%[\mathrm{vol} / \mathrm{vol}])$ and cocarboxylase $(5 \mu \mathrm{g} / \mathrm{ml})$ and in an atmosphere of $10 \% \mathrm{CO}_{2}-90 \% \mathrm{~N}_{2}$.
Cultures in PYG broth have a stringy or granular sediment and may be slightly turbid. After 5 to 7 days of incubation under $\mathrm{CO}_{2}-\mathrm{N}_{2}$, the $\mathrm{pH}$ of $\mathrm{PYG}$ and basal medium broth cultures is 6.9 to 7.1 ; under $100 \% \mathrm{CO}_{2}$, the $\mathrm{pH}$ of each is 6.0 to 6.2 .

Gas is not detected in PYG deep agar cultures; trace to moderate amounts of $\mathrm{H}_{2}$ may be produced. $\mathrm{H}_{2} \mathrm{~S}$ is not detected in sulfide-indole-motility medium.

No acid is produced from adonitol, amygdalin, Larabinose, cellobiose, dextrin, dulcitol, meso-erythritol, esculin, D-fructose, D-galactose, D-glucose, glycerol, glycogen, inositol, inulin, lactose, maltose, D-mannitol, Dmannose, melezitose, melibiose, pectin, raffinose, rhamnose, D-(-)ribose, salicin, D-sorbitol, L-sorbose, starch, sucrose, trehalose, or D-xylose. Indole, acetylmethylcarbinol, catalase, lecithinase, lipase, urease, oxidase, and deoxyribonuclease are not produced. Esculin, starch, and hippurate were not hydrolyzed. Nitrate is not reduced; neither resazurin nor neutral red is reduced. There is no reaction in milk and no digestion of gelatin or chopped meat.

The products of fermentation in PYG broth are moderate to large amounts of butyrate and trace to small amounts of acetate; traces of succinate are occasionally detected. Pyruvate, DL-lactate, D-gluconate, and L-threonine are utilized.

All 15 strains tested are susceptible to chloramphenicol (12 $\mu \mathrm{g} / \mathrm{ml})$, clindamycin $(1.6 \mu \mathrm{g} / \mathrm{ml})$, erythromycin $(3 \mu \mathrm{g} / \mathrm{ml})$, penicillin $(2 \mathrm{U} / \mathrm{ml})$, and tetracycline $(6 \mu \mathrm{g} / \mathrm{ml})$.

The principal habitat of $F$. sulci is the human gingival sulcus.

The type strain of $F$. sulci is VPI D45A-29A (=ATCC 35585). The guanine-plus-cytosine content of the DNA of this strain is 39 mol\%.

Strains of $F$. alocis, $F$. sulci, and $F$. russii can be distinguished most clearly by the electrophoretic patterns of their

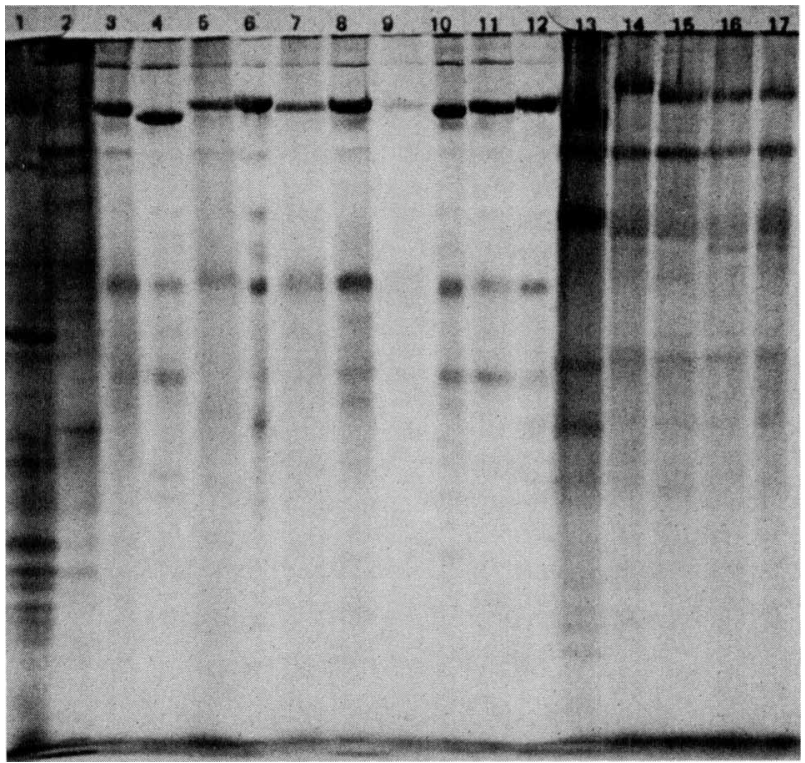

FIG. 2. Polyacrylamide gel electrophoresis protein patterns of Fusobacterium strains. Lane 1, S. faecalis U4-20, a reference strain; lane $2, F$. russii ATCC 25533 ${ }^{\mathrm{T}}$; lanes 3 through $12, F$. alocis ATCC $35896^{\mathrm{T}}$ (lane 3), D3A16 (lane 4), D6A6 (lane 5), D6B19 (lane 6), D40C8 (lane 7), D45B4 (lane 8), D61D29 (lane 9), D62D20 (lane 10), D73D11 (lane 11), and D84D7 (lane 12); lanes 13 through 17, F. sulci ATCC $35585^{\mathrm{T}}$ (lane 13), E4Y17 (lane 14), D25A5 (lane 15), D26C13 (lane 16), and D83A25 (lane 17). 
TABLE 1. Distribution of 117 isolates of $F$. alocis and 53 isolates of $F$. sulci in periodontal diseases ${ }^{a}$

\begin{tabular}{|c|c|c|c|c|c|c|}
\hline \multirow[b]{2}{*}{ Source ${ }^{b}$} & \multicolumn{2}{|c|}{$F$. alocis } & \multicolumn{2}{|c|}{ F. sulci } & \multirow{2}{*}{$\begin{array}{c}\text { Total } \\
\text { no. of } \\
\text { isolates }\end{array}$} & \multirow[b]{2}{*}{$\begin{array}{l}\text { No. of } \\
\text { people }\end{array}$} \\
\hline & $\begin{array}{c}\% \text { of } \\
\text { isolates }^{c}\end{array}$ & $\begin{array}{c}\% \text { of } 30 \\
\text { tested } \\
\text { samples }\end{array}$ & $\begin{array}{c}\% \text { of } \\
\text { isolates }^{d}\end{array}$ & $\begin{array}{c}\% \text { of } 30 \\
\text { tested } \\
\text { samples }\end{array}$ & & \\
\hline MP sub & 1.30 & 19.75 & 0.70 & 9.62 & 5,146 & 27 \\
\hline MP supra & 0.14 & 4.55 & 0.14 & 4.55 & 694 & 15 \\
\hline JP sub & 1.97 & 37.50 & 0 & 0 & 1,064 & 21 \\
\hline JP supra & 0.13 & 3.85 & 0.25 & 7.69 & 797 & 17 \\
\hline SP sub & 1.17 & 15.22 & 0.29 & 8.70 & 1,711 & 21 \\
\hline SP supra & 0.18 & 2.70 & 0.35 & 5.71 & 1,130 & 18 \\
\hline H sub & 0 & 0 & 0 & 0 & 956 & 19 \\
\hline H supra & 0.20 & 3.12 & 0.10 & 3.12 & 1,000 & 20 \\
\hline \multicolumn{7}{|l|}{ Adult } \\
\hline EGI0 & 0 & 0 & 0 & 0 & 562 & 4 \\
\hline NGI0 & 0 & 0 & 0 & 0 & 548 & 11 \\
\hline EGI1 & 0 & 0 & 0 & 0 & 1,332 & 4 \\
\hline NGI1 & 0 & 0 & 0.79 & 8.33 & 380 & 7 \\
\hline EGI2 & 0 & 0 & 0.09 & 2.78 & 1,141 & 4 \\
\hline NGI2 & 0.79 & 16.67 & 0 & 0 & 379 & 8 \\
\hline \multicolumn{7}{|l|}{ Child } \\
\hline EGI0 & 0 & 0 & 0 & 0 & 1,449 & 4 \\
\hline NGI0 & 0 & 0 & 0 & 0 & 318 & 7 \\
\hline EGI1 & 0 & 0 & 0 & 0 & 1,363 & 4 \\
\hline NGI1 & 0 & 0 & 0 & 0 & 220 & 4 \\
\hline EGI2 & 0 & 0 & 0 & 0 & 405 & 4 \\
\hline NGI2 & 0 & 0 & 0 & 0 & 122 & 3 \\
\hline
\end{tabular}

${ }^{a}$ Data in part are from references 5,6 , and 8 through 10 .

${ }^{b} \mathrm{MP}$, Moderate periodontitis; JP, juvenile periodontitis; SP, severe periodontitis; $\mathrm{H}$, gingiva of healthy persons; sub, subgingival samples taken from the depth of the sulcus; supra, supragingival samples taken from sites coronal to the subgingival sites sampled; EGI0, EGI1, and EGI2, subgingival sites with gingival index scores of 0 (healthy), 1 (inflamed), and 2 (bleeding), respectively, from subjects in experimental gingivitis trials; NGI0, NGI1, and NGI2, samples from subjects with naturally occurring gingivitis (gingival index scores are as for EGI0, EGI1, and EGI2, respectively.

$c$ Incidence of $F$. alocis in 20,717 isolates from 115 persons is $0.56 \%$

${ }^{d}$ Incidence of $F$. sulci in 20,717 isolates from 115 persons is $0.26 \%$

soluble cellular proteins (Fig. 1 and 2). The slow and sparse growth of $F$. alocis and $F$. sulci as compared with that of $F$. russii is a helpful differential characteristic. The production of significant amounts of $\mathrm{H}_{2}$ by $F$. alocis and little or none by $F$. sulci and $F$. russii also is useful.

$F$. alocis was more common in the gingival sulcus than was $F$. sulci (Table 1). Both species were more prevalent in the subgingival flora than in residual supragingival flora and in diseased than in healthy sites. No strains were isolated from experimental gingivitis in children; in developing gingivitis in young adults, both species were detected only when the gingiva were inflamed or bleeding. They may, therefore, contribute to the etiology of both gingivitis and periodontitis.

\section{ACKNOWLEDGMENTS}

We thank Pauletta C. Atkins, Karen S. Loferski, and Ann C. Ridpath for excellent technical assistance.

We gratefully acknowledge the financial support of Public Health Service grants AI-15244 from the National Institute of Allergy and Infectious Diseases and DE-05054 and DE-05139 from the National Institute of Dental Research.

\section{LITERATURE CITED}

1. Holdeman, L. V., E. P. Cato, and W. E. C. Moore (ed.). 1977. Anaerobe laboratory manual, 4th ed. Virginia Polytechnic Institute and State University, Blacksburg.

2. Johnson, J. L. 1981. Genetic characterization, p. 450-472. In P. Gerhardt, R. G. E. Murray, R. N. Costilow, E. W. Nester, W. A. Wood, N. R. Krieg, and G. B. Phillips (ed.), Manual of methods for general bacteriology. American Society for Microbiology, Washington, D.C.

3. Marmur, J., and P. Doty. 1962. Determination of the base composition of deoxyribonucleic acid from its thermal denaturation temperature. J. Mol. Biol. 5:109-118.

4. Moore, W. E. C., D. E. Hash, L. V. Holdeman, and E. P. Cato. 1980. Polyacrylamide slab gel electrophoresis of soluble proteins for studies of bacterial floras. Appl. Environ. Microbiol. 39:900-907.

5. Moore, W. E. C., L. V. Holdeman, E. P. Cato, R. M. Smibert, J. A. Burmeister, K. G. Palcanis, and R. R. Ranney. 1985. Comparative bacteriology of juvenile periodontitis. Infect. Immun. 48:507-519.

6. Moore, W. E. C., L. V. Holdeman, E. P. Cato, R. M. Smibert, J. A. Burmeister, and R. R. Ranney. 1983. Bacteriology of moderate (chronic) periodontitis in mature adult humans. Infect. Immun. 42:510-515.

7. Moore, W. E. C., L. V. Holdeman, and R. W. Kelley. 1984. Genus II. Fusobacterium Knorr 1922, 4AL, p. 631-637. In N. R. Krieg and J. G. Holt (ed.), Bergey's manual of systematic bacteriology, vol. 1. The Williams \& Wilkins Co., Baltimore.

8. Moore, W. E. C., L. V. Holdeman, R. M. Smibert, E. P. Cato, J. A. Burmeister, K. G. Palcanis, and R. R. Ranney. 1984. Bacteriology of experimental gingivitis in children. Infect. Immun. 46:1-6.

9. Moore, W. E. C., L. V. Holdeman, R. M. Smibert, I. J. Good, J. A. Burmeister, K. G. Palcanis, and R. R. Ranney. 1982. Bacteriology of experimental gingivitis in young adult humans. Infect. Immun. 38:651-667.

10. Moore, W. E. C., L. V. Holdeman, R. M. Smibert, D. E. Hash, J. A. Burmeister, and R. R. Ranney. 1982. Bacteriology of severe periodontitis in young adult humans. Infect. Immun. 38:1137-1148.

11. Moore, W. E. C., R. R. Ranney, and L. V. Holdeman. 1982. Subgingival microflora in periodontal disease: cultural studies, p. 13-26. In R. J. Genco and S. E. Mergenhagen (ed.), Hostparasite interactions in periodontal diseases. American Society for Microbiology, Washington, D.C.

12. Wilkins, T. D., and T. Thiel. 1973. A modified broth-disk method for testing the antibiotic susceptibility of anaerobic bacteria. Antimicrob. Agents Chemother. 3:350-356. 